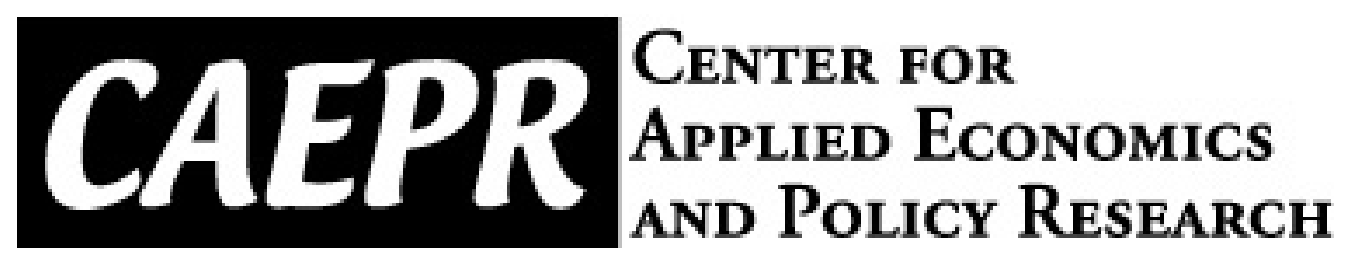

CAEPR Working Paper

\#006-2009

\title{
EXPECTATIONS AND FISCAL STIMULUS
}

\author{
TROY DAVIG AND ERIC M. LEEPER \\ Indiana University
}

May 19, 2009

This paper can be downloaded without charge from the Social Science Research Network electronic library at: http://ssrn.com/abstract=1416885.

The Center for Applied Economics and Policy Research resides in the Department of Economics at Indiana University Bloomington. CAEPR can be found on the Internet at:

http://www.indiana.edu/ caepr. CAEPR can be reached via email at caepr@indiana.edu or via phone at 812-855-4050.

(02008 by NAME. All rights reserved. Short sections of text, not to exceed two paragraphs, may be quoted without explicit permission provided that full credit, including $₫$ notice, is given to the source. 


\title{
EXPECTATIONS AND FISCAL STIMULUS
}

\author{
TROY DAVIG AND ERIC M. LEEPER
}

\begin{abstract}
Increases in government spending trigger substitution effects-both inter- and intra-temporal - and a wealth effect. The ultimate impacts on the economy hinge on current and expected monetary and fiscal policy behavior. Studies that impose active monetary policy and passive fiscal policy typically find that government consumption crowds out private consumption: higher future taxes create a strong negative wealth effect, while the active monetary response increases the real interest rate. This paper estimates Markov-switching policy rules for the United States and finds that monetary and fiscal policies fluctuate between active and passive behavior. When the estimated joint policy process is imposed on a conventional new Keynesian model, government spending generates positive consumption multipliers in some policy regimes and in simulated data in which all policy regimes are realized. The paper reports the model's predictions of the macroeconomic impacts of the American Recovery and Reinvestment Act's implied path for government spending under alternative monetary-fiscal policy combinations.
\end{abstract}

Date: May 19, 2009. Prepared for conference on "Monetary-Fiscal Policy Interactions, Expectations, and Dynamics in the Current Economic Crisis" at Princeton University, May 22-23, 2009. Research Department, Federal Reserve Bank of Kansas City, troy.davig@kc.frb.org; Department of Economics, Indiana University and NBER, eleeper@indiana.edu. The views expressed herein are those of the authors and do not necessarily represent those of the Federal Reserve Bank of Kansas City or the Federal Reserve System. 


\section{INTRODUCTION}

Monetary and fiscal policy responses to the recession of 2007-09 have been unusually aggressive, particularly in the United States. The Federal Reserve rapidly reduced the federal funds rate more than 500 basis points, beginning in summer of 2007, and the rate has effectively been at its zero bound since December 2008. Early this year the U.S. Congress passed the $\$ 787$ billion American Recovery and Reinvestment Act, in addition to the $\$ 125$ billion provided by the Economic Stimulus Act of 2008. The Congressional Budget Office (2009) projects that the Federal deficit will be 13 percent of GDP in 2009 and, with the passage of President Obama's budget, deficits will hover around 5 percent of GDP through 2019; as a consequence, government debt as a share of GDP is expected to rise from 40 percent to 80 percent. This unified and aggressive monetary-fiscal front to stimulate the economy is a distinctive feature of the current policy response.

The overriding objective of the stimulus efforts is to spur job creation by increasing aggregate demand, particularly in the short run [Romer and Bernstein (2009), Board of Governors of the Federal Reserve System (2008)]. Because private consumption constitutes about two-thirds of GDP, the typical argument has stimulus raise consumption demand, the demand for labor, and employment. It is ironic that the consumption response to an increase in government spending is the linchpin in the transmission mechanism for fiscal stimulus: economic theory does not universally support the idea that higher government purchases raise private consumption.

Two features of the macro policy response have received little modeling attention, despite being central to the predictions of the impacts of the policy actions. First, monetary and fiscal policy have reacted jointly in an effort to stimulate aggregate demand. A long line of research emphasizes that analyses that separate monetary and fiscal policies overlook policy interactions that are important for determining the equilibrium. ${ }^{1}$ Second, the current recession-fighting mix of macro policies is unlikely to persist indefinitely; eventually, policies will return to "normal." Because the impacts of current policies depend, in part, on expectations of possible future monetary-fiscal policy regimes, predictions need to condition on the current regime

\footnotetext{
${ }^{1}$ Examples include Sargent and Wallace (1981), Wallace (1981), Aiyagari and Gertler (1985), Sims (1988), and Leeper (1991).
} 
and incorporate prospective future regimes. ${ }^{2}$ Intertemporal aspects of monetary and fiscal policy interactions determine how any fiscal stimulus is expected to be financed, which ultimately determines the efficacy of the stimulus.

This paper addresses these two features in a conventional dynamic stochastic general equilibrium (DSGE) model with nominal price rigidities and complete specifications of monetary and fiscal policies. The model embeds the possibility that policy rules may evolve over time according to a known probability distribution and that private agents form expectations of policy according to that distribution. We estimate simple interest rate and tax policy rules whose parameters are governed by a Markov chain. The estimated joint monetary-fiscal policy process is inserted into the calibrated DSGE model. Government spending, which is a central focus of the analysis, evolves exogenously.

In this setting, an increase in unproductive government spending sets in motion both intra- and inter-temporal substitution effects, as well as a wealth effect. ${ }^{3,4}$ Relative sizes of these effects determine how real wages, employment, consumption, and inflation react. Typical analyses assume passive fiscal behavior, which couples higher government spending with an equivalent increase in lump-sum taxes to pay for the spending, while the analyses also assume active monetary policy [see, for example, Gali, Lopez-Salido, and Valles (2007), Ravn, Schmitt-Grohe, and Uribe (2007), and Monacelli and Perotti (2008)]..$^{5}$ Under this set of policies, the intra-temporal substitution effect is triggered when higher government spending increases aggregate demand and, because output is demand-determined, raises the demand for labor. As the real wage rises, households work harder, substituting consumption for leisure. An increase in the real wage is necessary for government spending to have a positive effect on private consumption. Higher real wages increase firms' marginal costs and

\footnotetext{
${ }^{2}$ Work along these lines is more limited, but includes Davig and Leeper (2006), Chung, Davig, and Leeper (2007), and Davig and Leeper (2007).

${ }^{3}$ We use the term 'unproductive' government spending to refer to those government purchases of goods and services that do not directly enhance the production possibilities or productivity of private firms.

${ }^{4}$ Monacelli and Perotti (2008) nicely explain how these mechanisms operate under flexible and sticky prices and under the two sets of preference specifications due to King, Plosser, and Rebelo (1988) and Greenwood, Hercowitz, and Huffman (1988).

${ }^{5}$ Monetary policy is passive when the central bank raises the nominal interest rate only weakly in response to inflation and fiscal policy is active when taxes and spending do not adjust in order to stabilize government debt [Leeper (1991)].
} 
cause them to raise prices, if given the opportunity under the Calvo (1983) pricing mechanism.

Inter-temporal effects work through the real interest rate, whose movements depend on how monetary policy responds to changes in inflation arising from changes in government purchases. When prices are sticky, an increase in government purchases gradually raises the price level, thereby raising the expected path of inflation. An active monetary response raises the nominal interest rate sharply, which raises the real rate and induces agents to postpone consumption. Higher taxes create a negative wealth effect that shifts out the supply of labor-when leisure is a normal good-further increasing hours worked, but offsetting at least some of the increase in real wage. Most importantly, because consumption is also a normal good, higher taxes induce the household to shift down its consumption path, ultimately reducing equilibrium consumption, as Barro and King (1984) and Baxter and King (1993) show.

Changes in government spending are most often studied in a regime with active monetary and passive fiscal policy. One exception is Kim (2003), who follows up on the analysis in Woodford (1998) to show that under alternative assumptions about the monetary-fiscal regime - specifically, passive monetary policy and active fiscal policy - higher government spending consistently raises both output and consumption. Under that alternative mix of policies, higher government spending also creates higher expected inflation. Instead of raising the real rate, passive monetary policy does not increase nominal rates strongly with inflation, so the real rate declines. The lower real rate reduces the return to saving and induces agents to increase current consumption demand. Active fiscal policy means that higher taxes are not expected to fully finance the increase in government spending, and the usual negative wealth effect on labor supply and consumption is mitigated, even with standard preferences such as those introduced by King, Plosser, and Rebelo (1988).

These substitution and wealth effects operate in the model with regime-switching policies, but their relative sizes vary across regimes. We explain these mechanisms using two viewpoints. The first is from the perspective of the firms and households' optimal decisions, as are explained above. A second viewpoint utilizes the intertemporal equilibrium condition that equates the value of nominal government liabilities 
to the expected present value of future net-of-interest surpluses inclusive of seigniorage revenues. ${ }^{6}$ From this standpoint, a higher expected path of government spending, with no associated higher path of taxes, reduces the fiscal backing for government liabilities, driving down their value. ${ }^{7}$ Households convert government debt into consumption, reinforcing the initial increase in aggregate demand. The value of debt in terms of goods must fall, so the price level must rise. Regime-switching policies imply that this debt revaluation mechanism is always in play, but its importance is a quantitative matter.

This paper reports quantitative results. Government spending multipliers for output - computed as the present value of the change in output as a ratio of the present value of the change in government spending - vary from a bit below 1 to near 2, depending on the monetary-fiscal regime that is assumed to prevail. The associated multipliers for consumption may be negative or close to one, depending on the policy regime. VARs estimated from simulated data in which policies fluctuate among all four possible combinations - one active and one passive; both passive; both active-yield mean government spending multipliers for output of about 1.7 and for consumption of about 0.7, close to estimates from the fiscal VAR literature.

The model in this paper assumes a fixed capital stock, which shuts off the possible channel that would allow consumption to rise by crowding out investment. Thus, our quantitative estimates are conservative relative to models that exploit this channel to raise the consumption multiplier.

The channels through which government spending affects prices and quantities in this paper seem highly plausible. They rely only on the observation that monetaryfiscal regimes change over time, fluctuating between active and passive periods. Otherwise, the environment we study is completely conventional. Existing methods for generating positive government spending multipliers for consumption do not conflict, and likely would amplify, the channels this work highlights.

\footnotetext{
${ }^{6}$ Leeper and Yun (2006) develop a Slutsky-Hicks decomposition to systematically study these effects in the context of changes in distorting taxes.

${ }^{7}$ Cochrane (2005, p. 502) refers to this intertemporal equilibrium condition as a "valuation equation for government debt."
} 


\section{Selective Review of Work on Government Spending}

In recent years, a small industry of research tries to reconcile the theoretical and empirical findings about the impacts of increases in unproductive government spending on private consumption. As initially pointed out by Barro and King (1984) and Baxter and King (1993), neo-classical theory predicts that higher government consumption that is financed by lump-sum taxes reduces household wealth and, therefore, the path of private consumption. In contrast, a range of empirical studies finds that government consumption crowds in private consumption [Blanchard and Perotti (2002), Perotti (2007), Ravn, Schmitt-Grohe, and Uribe (2007), Mountford and Uhlig (2009)]. ${ }^{8}$ Using U.S. data, Gali, Lopez-Salido, and Valles (2007) estimate the government spending multiplier for output to be 0.80 initially and rising to 1.74 after two years, while the multiplier for consumption is always positive and is 0.17 on impact and 0.95 after two years. Monacelli and Perotti (2008) report similar results across several empirical specifications.

A variety of theoretical channels have been suggested to ensure that the negative wealth effect on consumption does not overwhelm the substitution effect. Many suggestions amount to changing the representative household's preferences. Ravn, Schmitt-Grohe, and Uribe (2007), for example, assume deep habits that amplify the increase in real wages and, therefore, the size of the substitution effect. Monacelli and Perotti (2008) eliminate the wealth effect on labor supply, which generates strong complementarity between consumption and work effort. ${ }^{9}$

Gali, Lopez-Salido, and Valles (2007) is a departure from efforts to intervene on preferences, but the alternative is rather complex. Heterogenous agents - some fully optimizing and others operating by rules of thumb - are combined with imperfectly competitive labor markets - labor unions set wages - in a new Keynesian model with sticky prices to produce positive government spending multipliers for consumption.

\footnotetext{
${ }^{8}$ Not all empirical work supports the crowding in view. Ramey and Shapiro (1998) and Ramey (2007), for example, argue that anticipated increases in government spending reduce private consumption.

${ }^{9}$ Bouakez and Rebei (2007) intervene on preferences by assuming private consumption and public goods are complements. Linnemann (2006) obtains positive government spending multipliers for consumption in a frictionless real business cycle model by assuming particular non-separable preferences over consumption and leisure, but Bilbiie (2008) shows that Linnemann's preferences imply both a downward sloping labor supply function and that consumption is an inferior good.
} 
This paper combines an off-the-shelf new Keynesian model-described in the next section - with estimated regime-switching monetary and fiscal policies to explore more thoroughly the new channel that Kim (2003) points to by which government spending can have multiplied impacts on output and, therefore, produce positive multipliers for consumption.

\section{A New Keynesian Model with Variable Government Purchases}

The analysis is conducted in a conventional new Keynesian model with fixed capital and elastic labor supply. Nominal rigidities are introduced through Calvo (1983) pricing by monopolistically competitive final goods producing firms. Unproductive government spending is financed through a combination of lump-sum taxes, seigniorage revenues, and one-period nominal government bonds.

3.1. Households. The representative household chooses $\left\{C_{t}, N_{t}, M_{t}, B_{t}\right\}$ to maximize

$$
E_{t} \sum_{i=0}^{\infty} \beta^{i}\left[\frac{C_{t+i}^{1-\sigma}}{1-\sigma}-\chi \frac{N_{t+i}^{1+\eta}}{1+\eta}+\delta \frac{\left(M_{t+i} / P_{t+i}\right)^{1-\kappa}}{1-\kappa}\right]
$$

with $0<\beta<1, \sigma>0, \eta>0, \kappa>0, \chi>0$ and $\delta>0$, where $C_{t}$ is a composite consumption good consisting of differentiated goods, $c_{j t}$, which are aggregated using the Dixit and Stiglitz (1977) aggregator

$$
C_{t}=\left[\int_{0}^{1} c_{j t}^{\frac{\theta-1}{\theta}} d j\right]^{\frac{\theta}{\theta-1}}, \theta>1
$$

The household chooses each good $c_{j t}$ to minimize total expenditure, yielding the demand functions for each good $j$

$$
c_{j t}=\left(\frac{p_{j t}}{P_{t}}\right)^{-\theta} C_{t}
$$

where $P_{t} \equiv\left[\int_{0}^{1} p_{j t}^{1-\theta} d j\right]^{\frac{1}{1-\theta}}$.

The household's budget constraint is

$$
C_{t}+\frac{M_{t}}{P_{t}}+\frac{B_{t}}{P_{t}}+\tau_{t} \leq\left(\frac{W_{t}}{P_{t}}\right) N_{t}+\frac{M_{t-1}}{P_{t}}+\frac{\left(1+r_{t-1}\right) B_{t-1}}{P_{t}}+\Pi_{t},
$$


where $\tau_{t}$ is lump-sum taxes/transfers, $B_{t}$ are one-period nominal bond holding, $1+$ $r_{t-1}$ is the risk-free nominal interest rate between $t-1$ and $t$, and $\Pi_{t}$ is profits from the firm. The household maximizes (1) subject to (4), yielding

$$
\begin{gathered}
\chi \frac{N_{t}^{\eta}}{C_{t}^{-\sigma}}=\frac{W_{t}}{P_{t}} \\
1=\beta\left(1+r_{t}\right)\left(\frac{C_{t}}{C_{t+1}}\right)^{\sigma} \frac{P_{t}}{P_{t+1}} .
\end{gathered}
$$

resulting in the following relation between real money balances, the nominal rate and the composite consumption good,

$$
\frac{M_{t}}{P_{t}}=\delta^{\kappa}\left(\frac{r_{t}}{1+r_{t}}\right)^{-1 / \kappa} C_{t}^{\sigma / \kappa} .
$$

The government's demand for goods is in the same proportion as households, yielding the government's demand as $g_{j t}=\left(\frac{p_{j t}}{P_{t}}\right)^{-\theta} G_{t}$, where $G_{t}=\left[\int_{0}^{1} g_{j t}^{\frac{\theta-1}{\theta}} d j\right]^{\frac{\theta}{\theta-1}}$.

Necessary and sufficient conditions for household optimization require (5)-(7) hold for every period and household's budget constraints bind with equality, which implies that the present value of households' expected expenditures are bounded and the following transversality condition holds

$$
\lim _{T \rightarrow \infty} E_{t}\left[q_{t, T} \frac{A_{T}}{P_{T}}\right]=0,
$$

where $A_{t}=B_{t}+M_{t}$ and $q_{t, t+1}=\left(1+r_{t}\right) /\left(P_{t+1} / P_{t}\right)$.

3.2. Firms. A continuum of monopolistically competitive firms produce goods using labor. Production of good $j$ is

$$
y_{j t}=Z N_{j t}
$$

where $Z$ is aggregate technology, common across firms and taken to be constant.

Aggregating consumers' and government's demand, firm $j$ faces the demand curve

$$
y_{j t}=\left(\frac{p_{j t}}{P_{t}}\right)^{-\theta} Y_{t},
$$

where $Y_{t}$ is defined by

$$
C_{t}+G_{t}=Y_{t}
$$


Equating supply and demand for individual goods,

$$
Z N_{j t}=\left(\frac{p_{j t}}{P_{t}}\right)^{-\theta} Y_{t}
$$

Following Calvo (1983), a fraction $1-\varphi$ firms are permitted to adjust their prices each period, while the fraction $\varphi$ are not permitted to adjust. If firms are permitted to adjust at $t$, they choose a new optimal price, $p_{t}^{*}$, to maximize the expected discounted sum of profits given by

$$
E_{t} \sum_{i=0}^{\infty} \varphi^{i} q_{t, t+i}\left[\left(\frac{p_{t}^{*}}{P_{t+i}}\right)^{1-\theta}-\Psi_{t+i}\left(\frac{p_{t}^{*}}{P_{t+i}}\right)^{-\theta}\right] Y_{t+i}
$$

where the real profit flow of firm $j$ at period $t, \Pi_{j t}=\left(\frac{p_{j t}}{P_{t}}\right)^{1-\theta} Y_{t}-\frac{W_{t}}{P_{t}} N_{j t}$, has been rewritten using (12). $\Psi_{t}$ is real marginal cost, defined as

$$
\Psi_{t}=\frac{W_{t}}{Z P_{t}}
$$

The first-order condition that determines $p_{t}^{*}$ can be written as

$$
\frac{p_{t}^{*}}{P_{t}}=\left(\frac{\theta}{\theta-1}\right) \frac{E_{t} \sum_{i=0}^{\infty}(\varphi \beta)^{i}\left(Y_{t+i}-G_{t+i}\right)^{-\sigma}\left(\frac{P_{t+i}}{P_{t}}\right)^{\theta} \Psi_{t+i} Y_{t+i}}{E_{t} \sum_{i=0}^{\infty}(\varphi \beta)^{i}\left(Y_{t+i}-G_{t+i}\right)^{-\sigma}\left(\frac{P_{t+i}}{P_{t}}\right)^{\theta-1} Y_{t+i}}
$$

which we denote by

$$
\frac{p_{t}^{*}}{P_{t}}=\left(\frac{\theta}{\theta-1}\right) \frac{K_{1 t}}{K_{2 t}}
$$

where the numerator and the denominator have recursive representations:

$$
K_{1 t}=\left(Y_{t}-G_{t}\right)^{-\sigma} \Psi_{t} Y_{t}+\varphi \beta E_{t} K_{1 t+1}\left(\frac{P_{t+1}}{P_{t}}\right)^{\theta}
$$

and

$$
K_{2 t}=\left(Y_{t}-G_{t}\right)^{-\sigma} Y_{t}+\varphi \beta E_{t} K_{2 t+1}\left(\frac{P_{t+1}}{P_{t}}\right)^{\theta-1}
$$

Solving (16) for $p_{t}^{*}$ and using the result in the aggregate price index, $P_{t}^{1-\theta}=$ $(1-\varphi)\left(p_{t}^{*}\right)^{1-\theta}+\varphi P_{t-1}^{1-\theta}$, yields

$$
\pi_{t}^{\theta-1}=\frac{1}{\varphi}-\frac{1-\varphi}{\varphi}\left(\mu \frac{K_{1 t}}{K_{2 t}}\right)^{1-\theta}
$$


where $\mu \equiv \theta /(\theta-1)$ is the markup.

We assume that individual labor services may be aggregated linearly to produce aggregate labor, $N_{t}=\int_{0}^{1} N_{j t} d j$. Linear aggregation of individual market clearing conditions implies $Z N_{t}=\Delta_{t} Y_{t}$, where $\Delta_{t}$ is a measure of relative price dispersion defined by

$$
\Delta_{t}=\int_{0}^{1}\left(\frac{p_{j t}}{P_{t}}\right)^{-\theta} d j .
$$

Now the aggregate production function is given by

$$
Y_{t}=\frac{Z}{\Delta_{t}} N_{t}
$$

It is natural to define aggregate profits as the sum of individual firm profits, $\Pi_{t}=\int_{0}^{1} \Pi_{j t} d j$. Integrating over firms' profits and combining the household's and the government's budget constraints yields the aggregate resource constraint

$$
\frac{Z}{\Delta_{t}} N_{t}=C_{t}+G_{t}
$$

From the definitions of price dispersion and the aggregate price index, relative price dispersion evolves according to

$$
\Delta_{t}=(1-\varphi)\left(\frac{p_{t}^{*}}{P_{t}}\right)^{-\theta}+\varphi \pi_{t}^{\theta} \Delta_{t-1}
$$

where $\pi_{t}=P_{t} / P_{t-1}$.

Following Woodford (2003a), we define potential, or the natural level of, output, $Y_{t}^{p}$, to be the equilibrium level of output that would be realized if prices were perfectly flexible. Potential output, then, emerges from the model when $\varphi=0$, so all firms can adjust prices every period. In the current setup, potential would vary systematically with government spending, but not with monetary policy or tax policy shocks. In the empirical work, we use the Congressional Budget Office's measure of potential GDP, which is essentially a smooth trend for output, $Y_{t}^{T}$; it certainly does not coincide with the theoretical concept of the natural level of output. To make our theory line up with the empirical work, we define the output gap, $y_{t}$, as $y_{t}=Y_{t}-Y_{t}^{T}$, with $Y_{t}^{T} \equiv 1$ for all $t$. 


\section{Policy Specification}

4.1. Regime-Switching Policy Rules. To account for possible changes in regime, the policy rules take the same form as in Davig and Leeper (2006). Specifically, the monetary policy rule is

$$
r_{t}=\alpha_{0}\left(S_{t}^{M}\right)+\alpha_{\pi}\left(S_{t}^{M}\right) \pi_{t}+\alpha_{y}\left(S_{t}^{M}\right) y_{t}+\sigma_{r}\left(S_{t}^{M}\right) \varepsilon_{t}^{r},
$$

where $\pi_{t}$ is inflation, $y_{t}$ is the output gap, and $\varepsilon_{t}^{r} \sim$ i.i.d. $N(0,1)$ is the disturbance. $S_{t}^{M}$ indicates the monetary policy regime and follows a Markov chain with transition matrix $P^{M}$. The variance of the errors switch between two different values independently of the coefficients in the rule. Since coefficients may take two different regime-dependent values as well, there are a total of four monetary regimes. Estimates are given in table 1 and filtered and smoothed probabilities are given in figure 1. The sample runs from 1949:Q1 to 2008:Q4. The rule also includes a dummy to account for the credit controls in place in the early 1980s; however, its estimated value is insignificant.

The fiscal rule also takes the same form as in Davig and Leeper (2006). All parameters are restricted to switch simultaneously, so a change in behavior, say in the response of taxes to the output gap, imposes a change in the response to debt and government purchases. The fiscal rule is

$$
\tau_{t}=\gamma_{0}\left(S_{t}^{F}\right)+\gamma_{b}\left(S_{t}^{F}\right) b_{t-1}+\gamma_{y}\left(S_{t}^{F}\right) y_{t}+\gamma_{g}\left(S_{t}^{F}\right) g_{t}+\sigma_{\tau}\left(S_{t}^{F}\right) \varepsilon_{t}^{\tau},
$$

where $\tau_{t}$ is the ratio of lump-sum taxes - defined as government revenues less transfersto output, $b_{t-1}$ is lagged debt-to-output ratio, $g_{t}$ is the government purchase-tooutput ratio and $\varepsilon_{t}^{\tau} \sim N(0,1)$. $S_{t}^{F}$ indicates the fiscal policy regime, which follows a Markov chain with transition matrix $P^{F}$. The fiscal rule also allows the variance of the errors to switch between two values, but the changes are restricted to occur simultaneously with changes in the coefficients. Consequently, there are two fiscal regimes. The sample ends one quarter earlier than the sample for estimating the monetary rule due to data availability. Estimates are given in table 2 and filtered and smoothed probabilities are in figure 2 .

Fiscal policy has been active since President Bush's tax cuts began in 2001. The joint policy process throughout much of the 2000s has been passive monetary policy and active fiscal policy. 
When embedding the rules into the new Keynesian model, we take the same approach as in Davig and Leeper (2006) and aggregate the four monetary states into two states that differ across reaction coefficients. ${ }^{10}$ This has no impact on the numerical solution in the next section because although we estimate the policy rules allowing for random disturbances, we turn off the random shocks to taxes and monetary policy when solving the model. The only random disturbance we consider are to government purchases.

The aggregated transition matrix for monetary policy and estimated transition matrix for fiscal policy are as follows

$$
P^{M}=\left[\begin{array}{ll}
.97 & .03 \\
.01 & .99
\end{array}\right], \quad P^{F}=\left[\begin{array}{ll}
.94 & .06 \\
.05 & .95
\end{array}\right]
$$

The joint transition matrix governing the monetary-fiscal regime is then $P=$ $P^{M} \otimes P^{F}$. Figure 3 illustrates the estimated timing of the monetary-fiscal regime.

Government purchases evolve according to

$$
\log \left(G_{t}\right)=\log (\bar{G})(1-\rho)+\rho \log \left(G_{t-1}\right)+\varepsilon_{t},
$$

where $\varepsilon_{t} \sim N\left(0, \sigma^{2}\right)$.

4.2. The Government's Flow Budget Identity. The processes for $\left\{G_{t}, \tau_{t}, M_{t}, B_{t}\right\}$ must satisfy the flow government budget identity

$$
G_{t}=\tau_{t}+\frac{M_{t}-M_{t-1}}{P_{t}}+\frac{B_{t}}{P_{t}}-\frac{\left(1+r_{t-1}\right) B_{t-1}}{P_{t}} .
$$

given $M_{-1}>0$ and $\left(1+r_{-1}\right) B_{-1}$.

4.3. Steady-State Values. Steady-state debt levels conditional on the AM/PF, $\mathrm{PF} / \mathrm{PF}$ and $\mathrm{PM} / \mathrm{AF}$ regimes are set to be equal across regimes. Mechanically, this is done by substituting the tax rule into the budget constraint and setting output to

\footnotetext{
${ }^{10}$ The aggregation sums transition probabilities across volatility regimes, then weights each sum by the appropriate ergodic probability. For example, based on the definition of monetary regimes given in Table 1 , then $\operatorname{Pr}\left[S_{t}=1 \mid S_{t-1}=1\right] \equiv$ $\left(\operatorname{Pr}\left[S_{t}^{M}=1\right]+\operatorname{Pr}\left[S_{t}^{M}=2\right]\right)\left(\operatorname{Pr}\left[S_{t}^{M}=1 \mid S_{t-1}^{M}=1\right]+\operatorname{Pr}\left[S_{t}^{M}=1 \mid S_{t-1}^{M}=2\right]\right)$, where $S_{t}$ is the aggregated regime, $S_{t}^{M}=1$ is the low-volatility active regime and $S_{t}^{M}=2$ is the high-volatility active regime.
} 
its deterministic steady state level of unity, then solving for the intercept in the tax policy rule. These calculations yield

$$
\gamma_{0}\left(S_{t}^{F}\right)=G-m\left(\frac{\pi}{1+\pi}\right)-b\left(1+\gamma\left(S_{t}^{F}\right)-\frac{\beta^{-1}}{(1+\pi)}\right),
$$

where each variable, except $\gamma_{0}\left(S_{t}^{F}\right)$ and $\gamma\left(S_{t}^{F}\right)$ is set to its steady-state value. A similar procedure is done with the monetary policy rule, $(24)$, and the money demand relation, (7). As with debt, steady-state rates of inflation are set to be equal across the $\mathrm{AM} / \mathrm{PF}, \mathrm{PF} / \mathrm{PF}$ and $\mathrm{PM} / \mathrm{AF}$ regimes.

For the $\mathrm{AM} / \mathrm{AF}$ regime, steady-state debt is not a well defined concept, since debt follows a nonstationary path. In this regime, an innovation to the level of debt does not elicit a sufficient response from future taxes to stabilize the path of debt. However, the active-active regime is not expected to last indefinitely, as the transversality condition on debt is satisfied via an expectation of a switch to a future policy regime.

\section{Solution And Calibration}

We set the parameters governing preferences, technology and price adjustment to be consistent with Rotemberg and Woodford (1997) and Woodford (2003b). The model is calibrated at a quarterly frequency. Firms markup the price of their good over marginal cost by 15 percent, implying $\mu=\theta(1-\theta)^{-1}=1.15$, and 66 percent of firms cannot reset their price each period $(\varphi=.66)$. The quarterly real interest rate is set to 1 percent $(\beta=.99)$. Preferences over consumption is logarithmic, so $\sigma=1$. We also set the Frisch labor supply elasticity to unity, so $\eta=1$ and set $\chi$ so the steady state share of time spent in employment is 0.2 . Intermediate goods-producing firms utilize a constant-returns-to-scale production function. The technology parameter, $Z$, is set to normalize the deterministic steady state level of output to unity. Steady state inflation is set to 2 percent and the steady state debt-output ratio is set to .35 .

For real balances, we set $\delta$ so velocity in the deterministic steady state, defined as $c P / M$, corresponds to the average U.S. monetary base velocity at 2.4 . We take this

value from Davig and Leeper (2006), where we computed it using data from 1959-2004 on the average real level of expenditure on non-durable consumption plus services. The parameter that determines the interest elasticity of real money balances, $\kappa$, is set 
to 2.6 [Mankiw and Summers (1986), Lucas (1988), Chari, Kehoe, and McGrattan (2000)].

Coefficients in the monetary and fiscal rules are set to their estimated values with one exception: the coefficient on government purchases in the fiscal rule is set to zero. The actual estimates for these coefficients are positive and imply that taxes begin rising in the same period as the increase in government purchases. Ruling out the immediate tax response to government purchases better isolates the impact of government purchases. Taxes continue to respond, however, to the movements in debt and output generated by the change in government purchases.

To obtain parameter values in the process for government purchases, we estimate $\rho$ and $\sigma^{2}$ by detrending the log of real total government purchases from 1949:Q12009:Q1 and then estimate (27). Estimation yields a value for $\rho$ of .9 and the value of $\sigma^{2}$ implies a one-standard deviation shock raises the level of government purchases $1.5 \%$. Steady state purchases, $\bar{G}$, is set so purchases equal $20 \%$ of output in the the deterministic steady state.

We solve the model numerically using the same method as in Davig and Leeper (2006).

\section{Dynamic Impacts of Government Purchases}

In the new Keynesian framework, the general mechanisms through which a change in government purchases affects the equilibrium, regardless of the monetary-fiscal regime, are:

- higher government spending raises demand for the goods sold by monopolistically competitive intermediate-goods producing firms;

- intermediate-goods producing firms meet demand at posted prices by increasing their demand for labor;

- higher labor demand raises real wages, real marginal costs;

- firms that have the option of reevaluating their pricing decision will increase their prices.

These mechanisms operate across each monetary-fiscal regime. Also, the positive comovement of output and prices occurs in each regime, so an unproductive government spending shock looks like a traditional "demand" shock regardless of policy. 
The policy regime, however, does play a critical role in determining the movement of real rates, consumption and the path for inflation.

To highlight the differences and similarities across regimes, figure 4 reports the impulse responses to a two-standard deviation shock to government purchases, which translates to a 3 percent rise in the level of purchases, conditional on each of the three stationary regimes. The experiment holds regime fixed, although agents' expectations functions embed the probability that regimes can change. In each regime, output rises as government purchases increase demand, causing firms to hire more labor and increase production. Households experience a rise in their real wage due to the increase in demand for their labor services (i.e. they slide along their labor supply curve), but also realize some decline in wealth arising from higher expected tax payments. From the monopolistic firms' perspective, the rise in the real wage drives up their real marginal costs. Since government purchases are serially correlated, the rise in marginal costs is expected to be persistent; if given the opportunity under the Calvo pricing restrictions, an individual firm will respond to the shock by raising their price.

Under active monetary and passive fiscal policy, which is the benchmark policy configuration in many studies and exhibits Ricardian equivalence in the fixed-regime setting, the monetary authority responds aggressively to the rise in inflation by increasing the nominal rate more than one-for-one. As figure 4 indicates, the monetary response persistently raises the real rate and dampens consumption demand from households. As purchases return to their steady state level, the real rate falls and consumption rises back to steady state. Since inflation remains relatively subdued, seigniorage revenues play a small role in governing debt dynamics. Taxes respond to lagged debt and rise as the government issues debt to finance the expanded level of purchases. However, taxes do not respond sufficiently to result in monotonically declining debt, so debt peaks roughly 10 periods after the initial shock.

The dynamics of output and consumption in the active monetary/passive fiscal $(\mathrm{AM} / \mathrm{PF})$ regime qualitatively resemble those of a standard real-business cycle model, where an increase in government purchases acts as a negative shock to lifetime wealth, which causes agents to decrease both consumption and leisure. The rise in time spent working stimulates output, but not enough to cause consumption to rise. The drop in consumption, both in the $\mathrm{AM} / \mathrm{PF}$ regime and real business cycle model stands in contrast to traditional Keynesian policy analysis. Textbook formulations posit that 
an increase in government purchases generates dynamics - sometimes referred to as "Keynesian hydraulics" - that produce a multiple increase in output and consumption, where the multiple depends on the marginal propensity to consume [Branson (1989)].

As discussed in the introduction, mechanisms that cause consumption to rise in modern general equilibrium settings often require modifying preferences or introducing incomplete markets and labor market rigidities. An alternative to these larger modifications is to assume a different policy regime with passive monetary and active fiscal policy. Kim (2003) shows in a fixed-regime new Keynesian model that an increase in government purchases can increase consumption under passive monetary/active fiscal (PM/AF) policy by inducing the real rate to decline. Figure 4 demonstrates that the same mechanism exists in the regime-switching framework. The increase in government purchases, which is expected to be persistent, raises current and future demand, so raises inflation expectations. Under passive monetary policy, the monetary authority responds to the increase in inflation less than one-for-one and lets the real rate fall. The lower future path of the real rate lowers the return to saving, which stimulates household demand as they pull consumption forward. This model holds the capital stock fixed and is a closed economy, so the increase in government purchases and consumption generates an output multiplier greater than one and a larger increase in output than under AM/PF policy. The large increase in output above potential generates a substantially larger increase in inflation than in the $\mathrm{AM} / \mathrm{PF}$ regime.

The larger response of output under passive monetary policy also raises taxes by more on impact than under active monetary policy, since the tax rule specifies taxes rise in response to the output gap. Under passive monetary/passive fiscal $(\mathrm{PM} / \mathrm{PF})$ policy, the response of taxes to output is larger than in $\mathrm{PM} / \mathrm{AF}$, so taxes increase relatively more and debt rises by less on impact.

To better understand the debt dynamics, recall that following intertemporal equilibrium condition must hold in every regime

$$
\frac{M_{t-1}+\left(1+r_{t-1}\right) B_{t-1}}{P_{t}}=E_{t} \sum_{T=t}^{\infty}\left[q_{t, T}\left(\tau_{T}-G_{T}+\frac{r_{T}}{1+r_{T}} \frac{M_{T}}{P_{T}}\right)\right]
$$


which indicates that the present value of primary surpluses and seigniorage must equal the real value of outtanding nominal government liabilities. Holding everything constant except government purchases, (30) implies that an increase in government purchases, financed by new debt issuance, lowers the present value of primary surpluses and creates an imbalance between the initial value of liabilities and their expected backing (i.e. the right-hand side variables).

To restore balance, a number of adjustments can occur. First, the present value of taxes may rise by exactly the amount that government purchases changed, which is the adjustment that occurs under Ricardian equivalence. Second, the present value of seigniorage may rise. Third, the current price level may jump, revaluing existing liabilities. In the regime switching setting, all of these adjustments occur and the relative importance of each adjustment for reestablishing equilibrium condition (30) depends on the joint monetary-fiscal policy process.

At each point in time, real debt must be backed by the present value of primary surpluses and seigniorage, which depend on how the policy process is expected to evolve. A policy combination that implies less total backing will cause agents to try to substitute out of real debt holdings, which will be consistent in equilibrium with a rise in consumption demand. The rise in demand increases the current price level to a level that restores balance between the left- and right-hand sides of (30). The rise in the price level can then be understood from two perspectives, either the firm's pricing decision or the intertemporal equilibrium condition (30).

Figure 5 decomposes the debt dynamics between changes in the present value of primary surpluses and seigniorage. The upper-left panel reports the paths for debt in different regimes and the lower two panels report the responses of the present value of primary surpluses and seigniorage. The paths for primary surpluses and seigniorage are given in terms of percentage changes, which are then weighted by their share of debt. Define $x_{t}$ to be the expected present value of primary surpluses and $z_{t}$ to be the expected present value of seigniorage, beginning at $t+1$. Rewrite (30) as $\frac{B_{t}}{P_{t}}=x_{t}+z_{t}$, which log-linearized becomes

$$
\widehat{b}_{t}=\frac{\bar{x}}{\bar{b}} \widehat{x}_{t}+\frac{\bar{z}}{\bar{b}} \widehat{z}_{t}
$$

where bars denote steady state values conditional on regime and hats denote the log deviations. Equation (31) indicates that the percentage change in debt is a weighted 
average of the percentage changes in the present value of surpluses and seigniorage. ${ }^{11}$ The reason then for weighting the responses of primary surpluses and seigniorage in Figure 5 is that the linear aggregation of each value approximates the change in debt, which eases the interpretation of determining the driving forces behind debt dynamics.

In figure 5, debt rises under $\mathrm{AM} / \mathrm{PF}$ and is backed by roughly an equal rise in both primary surpluses and seigniorage. The rise in government purchases exerts downward pressure on the present value of primary surpluses, but primary surpluses rise due to higher expected taxes due to passive fiscal policy. In contrast, the present value of primary surpluses falls under passive monetary policy and seigniorage rises. The recovery of the present value of primary surpluses to its steady state under passive policy is slow relative to the return of seigniorage. Thus, the backing of debt actually falls below its steady state debt level as seigniorage falls, causing debt to fall below its steady state level.

\section{Government Purchase Multipliers}

7.1. Impact vs. Present Value Multipliers. Empirical studies that measure the effect of exogenous changes in government purchases, such as Blanchard and Perotti (2002), report the following impact multiplier

$$
\text { Impact Multiplier }(k)=\frac{\Delta Y_{t+k}}{\Delta G_{t}},
$$

which is the increase in the level of output $j$ periods ahead in response to an increase in government purchases equal to size $\Delta G_{t}$ at time $t$.

There are several issues with this definition of the multiplier. First, if the process governing government purchases is serially correlated, then a change in government purchases portends a path of future government purchases. Measuring the impact on output using $\Delta Y_{t+j} / \Delta G_{t}$ does not take into account how expected future purchases impact $\Delta Y_{t+j}$, so this measure can easily be biased. Second, $\Delta Y_{t+j} / \Delta G_{t}$ is not in present value units, so a unit increase in output 50 years in the future is treated as

\footnotetext{
${ }^{11}$ In the figure, the sums of $\widehat{x}_{t}$ and $\widehat{z}_{t}$ do not exactly equal $\widehat{b}_{t}$ due to the approximation error arising from the log-linearization of (30).
} 
equivalent to a unit increase in output this year. Without discounting, the multiplier calculation can be a misleading guide to policy decisions. ${ }^{12}$

To remedy both of these issues, we follow the measure in Mountford and Uhlig (2009) and report the change in the present value of additional output over different horizons generated by a $\$ 1$ change in the present value of government purchases,

$$
\text { Present Value Multiplier }(k)=\frac{E_{t} \sum_{j=0}^{k} \prod_{i=0}^{j}\left(1+r_{t+i}\right)^{-j} \Delta Y_{t+k}}{E_{t} \sum_{j=0}^{k} \prod_{i=0}^{j}\left(1+r_{t+i}\right)^{-j} \Delta G_{t+k}} .
$$

In our context, this is the increase in the present value of output over the next $k$ periods, conditional on holding the prevailing monetary and fiscal regime fixed.

7.2. Multipliers Across Monetary-Fiscal Regimes. Table 3 reports the present value output multipliers over different horizons conditioning on each of the stationary regimes. In general, the long-run government multiplier is greater than unity for regimes with passive monetary policy, which implies the consumption multiplier in these policy regimes is positive. The positive consumption multiplier arises for reasons explained early - passive monetary policy allows the real rate to fall, which raises aggregate consumption demand. The output multiplier is slightly larger under active fiscal policy because agents expected relative lower future taxes relative to the passive fiscal regime. To be precise, roughly $91 \%$ of the increase in government purchases is backed by higher future taxes under the $\mathrm{PM} / \mathrm{PF}$ regime, whereas it is $89 \%$ under the $\mathrm{PM} / \mathrm{AF}$ regime. The slightly larger tax liability under the $\mathrm{PM} / \mathrm{PF}$ regime explains the slightly lower multipliers.

Table 4 reports the impacts of government purchases on the price level, which generally mimic the pattern for the multipliers. The larger the increase in demand, or final output, as measured by the multipliers, the larger is the impact on the price level. Not surprisingly, the largest impacts on the price level occurs under passive monetary policy.

\footnotetext{
${ }^{12}$ Romer and Bernstein (2009) use impact multipliers to project the likely impacts of the 2009 stimulus package. One reason, however, that empirical work does not often report discounted values is because discount factors are not readily available.
} 
7.3. Simulating Time Series. Suppose that the model in section 3 were the true data generating process and an econometrician employs standard VAR techniques to identify the impacts of an exogenous change in government spending. What multipliers for output and consumption will the econometrician obtain?

To simulate the time series we draw sequences of the government spending shock and the monetary and fiscal policy states, $\left\{\varepsilon_{t}^{g}, S_{t}^{M}, S_{t}^{F}\right\}_{t=1}^{T}$, and solve the nonlinear model for each date $t$. Setting $T=500$, we discard the first 250 periods, ensuring that the model has settled into its ergodic distribution. From this we have one sample of equilibrium data of length 250 periods, roughly comparable to a post-war quarterly sample. For each sample we estimate a bivariate VAR in government spending and consumption. We order $G_{t}$ first and use a Choleski decomposition to identify an exogenous shock to spending. ${ }^{13}$

Figure 6 plots the mean and 68 percent probability band for responses of government spending and private consumption to a serially correlated shock to $G_{t}$ normalized to equal $\$ 1$ in the initial period. We compute impact multipliers to be comparable to empirical work. Private consumption responds strongly on impact, with a mean jump of over 80 cents. The multiplier remains positive for about six quarters before turning mildly negative. Multipliers in this range are reported by Monacelli and Perotti (2008) for U.S. data, though their estimates imply a weak initial response of consumption that gradually builds to a peak 8 to 10 quarters after the shock. Our simple model has little internal propagation, so the large impact effect and rapid decay are to be expected. Nonetheless, the figure shows that the setup in which monetary and fiscal regimes fluctuate over time is capable of generating consumption responses of the magnitude observed in U.S. time series.

\section{Simulating Fiscal Simulus: The 2009 ARRA}

The American Recovery and Reinvestment Act of 2009 is the fiscal stimulus packaged passed by Congress with the primary intention of stabilizing economic activity

\footnotetext{
${ }^{13}$ In simulations where the regime realizations produce active monetary and active fiscal policy, debt temporarily assumes a nonstationary path because neither the monetary or fiscal authority is acting in a manner that ensures long-run solvency. When the doubly active regime persists too long, the solution moves far off the grid for the discretized state space and approximation errors can produce imply economically infeasible solutions. We discard any draws that exhibit such behavior, leaving us with 571 samples of time series.
} 
following the sharp decline in output late in 2008. The total size of the package is $\$ 787$ billion and comprises both additional government spending and tax cuts. This section illustrates that the likely impact of the stimulus rests with how monetary and fiscal policies respond going forward.

In line with the focus of the paper thus far, we analyze the impact of the additional purchases contained in the stimulus package. The stimulus package contains spending on infrastructure, healthcare, energy, and so forth and it includes $\$ 144$ billion in federal transfers to state and local governments. These transfers do not necessarily need to go towards increasing purchases, but instead could be used to avoid tax hikes or borrowing. Following Romer and Bernstein (2009) and Cogan, Cwik, Taylor, and Wieland (2009), we assume that 60 percent of the transfers to state and local governments go towards increasing purchases. Using this assumption, Cogan, Cwik, Taylor, and Wieland (2009) report the increase in government purchases, on a yearly basis, due to the stimulus package.

Figure 7 compares the paths of several variables in response to the path of the additional government purchases from the ARRA as estimated from Cogan, Cwik, Taylor, and Wieland (2009). We compute responses under both $\mathrm{AM} / \mathrm{PF}$ and PM/AF. Under $\mathrm{AM} / \mathrm{PF}$ (solid lines), the active monetary response drives up the real rate in response to the increase in purchases. Total output and inflation, however, follow a hump-shape and peak roughly at the same time as the peak in additional purchases. Note that fiscal financing of the increase in spending occurs very gradually, with both debt and taxes above their steady state levels for many years.

Under PM/AF (dashed lines), passive monetary policy allows the real rate to fall, so stimulates consumption demand. Inflation peaks nearly 300 basis points above its steady state level about 5 quarters after the initial impulse. Relatively high inflation erodes the real value of outstanding debt, leaving it considerably below its level in the $\mathrm{AM} / \mathrm{PF}$ regime.

To obtain a sense of how much future variability can be attributed to shifts in policy regime, figure 8 reports the mean response of a monte carlo exercise that uses the Cogan, Cwik, Taylor, and Wieland (2009) path for government purchases, but randomly draws over regimes. Dashed lines represent two-standard deviation bands computed at each point in time. The initial regime is set to PM/AF, so the initial rise in government purchases is often occurring under this same regime, since it is relatively persistent. Persistence of the regime causes the mean response of the real 
rate to fall, but then assumes a less certain path as the effect of some draws of active monetary policy are realized.

Table 5 formally quantifies the ARRA path of Cogan, Cwik, Taylor, and Wieland (2009) in terms of output multipliers. One issue that arises in such computations is whether agents fully internalize the future path of government purchases, or are surprised each period - that is, they have no foresight about the stimulus package. One method to incorporate foresight is to modify the process for government purchases by adding moving average terms to the government purchase process and convert it to an ARMA $(1,5)$. We calibrate the moving average coefficients using a minimum distance estimator based on the Cogan, Cwik, Taylor, and Wieland (2009) path and impulse response of the $\operatorname{ARMA}(1,5)$. Under the $\operatorname{ARMA}(1,5)$ process, a shock to purchases implies a path similar to that of the ARRA, except agents have full knowledge of its trajectory. The ARMA $(1,5)$ adds five state variables, which renders the nonlinear solution method for the regime-switching model impractical. To obtain a sense of how important fiscal foresight is, we move to a linear fixed-regime setting.

The top portion of table 5 reports the multipliers under the assumption of no foresight. A similar pattern emerges as in the regime-switching setting following the $\mathrm{AR}(1)$ shock, except the multipliers under the PM/AF regime are considerably larger. Under foresight, however, agents have knowledge of the rising level of purchases so substantially revise up their expectations of future inflation in response to a shock. The passive monetary response causes a sharp drop in the real rate and the large multiplier, which is 4.83 after five quarters under PM/AF. In contrast, the monetary authority responds aggressively to the higher inflation in the AM/PF, which pushes the real rate higher relative to the case of no foresight and dampens the multiplier.

\section{Conclusion}

This paper has embedded estimated Markov-switching rules for U.S. monetary and fiscal policy into an otherwise conventional calibrated DSGE model with nominal rigidities to deliver some quantitative predictions of the impacts of government spending increases. When monetary and fiscal policy regimes vary-from active monetary/passive fiscal to passive monetary/active fiscal to doubly passive to doubly active - government spending multipliers can vary widely. An increase in government spending of $\$ 1$ in present value raises output by $\$ 0.80$ in present value under $\mathrm{AM} / \mathrm{PF}$, while it raises output by as much as $\$ 1.80$ in present value when monetary 
policy is passive. In our simple model, this translates into a decrease in consumption of $\$ 0.20$ in present value under $\mathrm{AM} / \mathrm{PF}$, but and increase in consumption of about $\$ 0.80$ in present value under passive monetary policy.

The paper also simulates the general equilibrium impacts of the government spending path implied by the 2009 American Recovery and Reinvestment Act. When the government spending path is modeled as a sequence of shocks to spending, the present-value multiplier for output is about $\$ 0.68$ under a fixed regime of $\mathrm{AM} / \mathrm{PF}$, while it can be well over $\$ 3.00$ in a fixed $\mathrm{PM} / \mathrm{AF}$ regime. If the government spending path is treated as foreseen by economic agents - because the path is announced by the passage of the Act - the present-value multiplier for output falls somewhat when the regime is $\mathrm{AM} / \mathrm{PF}$, but it rises to nearly $\$ 5.00$ in the short run when policy obeys a $\mathrm{PM} / \mathrm{AF}$ regime.

\section{Appendix A. Data Description: Fiscal Variables}

The fiscal policy variables we use in estimating the switching fiscal rule (25) are at a quarterly frequency and defined as follows:

- $\tau_{t}=($ Federal Receipts - Federal Transfers $) /($ Nominal GDP)

- Federal Receipts: Line 1 of NIPA Table 3.2

- Federal Transfers: Line 21 of NIPA Table 3.2

- Nominal GDP: Line 1 of NIPA Table 1.1.5

- $b_{t}=\sum_{j=0}^{3}$ (Market value of privately held gross federal debt $)_{t-j} /(\text { Nominal GDP })_{t-j}$

- Debt series available from Federal Reserve Bank of Dallas website

- $y_{t}=\ln$ (Nominal GDP/Nominal CBO potential GDP)

- Nominal CBO potential GDP available from Congressional Budget Office website

- $g_{t}=$ (Nominal Federal government consumption expenditures and gross investment)/(Nominal GDP)

- Nominal Federal government consumption expenditures and gross investment: Line 21 of NIPA Table 1.1.5 


\section{REFERENCES}

Aiyagari, S. R., And M. Gertler (1985): "The Backing of Government Debt and Monetarism," Journal of Monetary Economics, 16(1), 19-44.

Barro, R. J., And R. G. King (1984): "Time-Separable Preferences and Intertemporal-Substitution Models of Business Cycles," Quarterly Journal of Economics, 99(4), 817-839.

Baxter, M., And R. G. King (1993): "Fiscal Policy in General Equilibrium," American Economic Review, 86, 1154-1174.

Bilbite, F. (2008): "Non-Separable Preferences, Fiscal Policy Puzzles and Inferior Goods," forthcoming in Journal of Money, Credit and Banking.

Blanchard, O. J., and R. Perotti (2002): "An Empirical Characterization of the Dynamic Effects of Changes in Government Spending and Taxes on Output," Quarterly Journal of Economics, 117(4), 1329-1368.

Board of Governors of the Federal Reserve System (2008): "Press Release: Federal Open Market Committee," October 29.

Bouakez, H., And N. Rebei (2007): "Why Does Private Consumption Rise After a Government Spending Shock?," Canadian Journal of Economics, 40(3), 954-979.

Branson, W. H. (1989): Macroeconomic Theory and Policy. Harper and Row, New York, 3rd edn.

Calvo, G. A. (1983): "Staggered Prices in a Utility Maximizing Model," Journal of Monetary Economics, 12(3), 383-398.

Chari, V. V., P. J. Kehoe, and E. R. McGrattan (2000): "Sticky Price Models of the Business Cycle: Can the Contract Multiplier Solve the Persistence Problem?," Econometrica, 68(5), 1151-1179.

Chung, H., T. Davig, and E. M. Leeper (2007): "Monetary and Fiscal Policy Switching," Journal of Money, Credit and Banking, 39(4), 809-842.

Cochrane, J. H. (2005): "Money as Stock," Journal of Monetary Economics, $52(3), 501-528$.

Cogan, J. F., T. Cwik, J. B. Taylor, and V. Wieland (2009): "New Keynesian versus Old Keynesian Government Spending Multipliers," Manuscript, Stanford University.

Congressional Budget Office (2009): A Preliminary Analysis of the President's Budget and an Update of CBO's Budget and Economic Outlook, vol. March. CBO, Washington, D.C. 
Davig, T., And E. M. Leeper (2006): "Fluctuating Macro Policies and the Fiscal Theory," in NBER Macroeconomics Annual 2006, ed. by D. Acemoglu, K. Rogoff, and M. Woodford, pp. 247-298. MIT Press, Cambridge.

- (2007): "Generalizing the Taylor Principle," American Economic Review, $97(3), 607-635$.

Dixit, A. K., And J. E. Stiglitz (1977): "Monopolistic Competition and Optimum Product Diversity," American Economic Review, 67(3), 297-308.

Gali, J., J. D. Lopez-SAlido, And J. VAlles (2007): "Understanding the Effects of Government Spending on Consumption," Journal of the European Economic Association, 5(1), 227-270.

Greenwood, J., Z. Hercowitz, and G. W. Huffman (1988): "Investment, Capacity Utilization, and the Real Business Cycle," American Economic Review, 78(3), 402-417.

KIm, S. (2003): "Structural Shocks and the Fiscal Theory of the Price Level in the Sticky Price Model," Macroeconomic Dynamics, 7(5), 759-782.

King, R. G., C. I. Plosser, and S. T. Rebelo (1988): "Production, Growth, and Business Cycles: I. The Basic Neoclassical Model," Journal of Monetary Economics, 21(March/May), 195-232.

Leeper, E. M. (1991): 'Equilibria Under 'Active' and 'Passive' Monetary and Fiscal Policies," Journal of Monetary Economics, 27(1), 129-147.

Leeper, E. M., And T. Yun (2006): "The Fiscal Theory of the Price Level: Background and Beyond," International Tax and Public Finance, 13(4), 373-409.

Linnemann, L. (2006): "The Effect of Government Spending on Private Consumption: A Puzzle?," Journal of Money, Credit and Banking, 38(7), 1715-1735.

LucAs, JR., R. E. (1988): "Money Demand in the United States: A Quantitative Review," Carneige-Rochester Conference Series on Public Policy, pp. 137-168.

Mankiw, N. G., And L. H. Summers (1986): "Money Demand and the Effects of Fiscal Policies," Journal of Money, Credit, and Banking, 18(4), 415-429.

Monacelli, T., And R. Perotti (2008): "Fiscal Policy, Wealth Effects, and Markups," NBER Working Paper No. 14584.

Mountford, A., And H. Uhlig (2009): "What Are the Effects of Fiscal Policy Shocks?," forthcoming in Journal of Applied Econometrics.

Perotti, R. (2007): "In Search of the Transmission Mechanism of Fiscal Policy," in NBER Macroeconomics Annual 200\%, ed. by D. Acemoglu, K. Rogoff, and M. Woodford, vol. 22, pp. 169-226. University of Chicago Press, Chicago, NBER Working Paper No. 13143. 
Ramey, V. A. (2007): "Identifying Government Spending Shocks: It's All in the Timing," Manuscript, University of California, San Diego.

Ramey, V. A., And M. D. Shapiro (1998): "Costly Capital Reallocation and the Effects of Government Spending," Carneige-Rochester Conference Series on Public Policy, 48, 145-194.

Ravn, M. O., S. Schmitt-Grohe, and M. Uribe (2007): "Explaining the Effects of Government Spending Shocks on Consumption and the Real Exchange Rate," NBER Working Paper No. 13328.

Romer, C., And J. Bernstein (2009): The Job Impact of the American Recovery and Reinvestment Plan. Obama Transition Team, Washington, D.C., January 9.

Rotemberg, J. J., And M. Woodford (1997): "An Optimization-Based Econometric Framework for the Evaluation of Monetary Policy," in NBER Macroeconomics Annual 1997, ed. by B. S. Bernanke, and J. J. Rotemberg, pp. 297-346. MIT Press, Cambridge, MA.

Sargent, T. J., And N. Wallace (1981): "Some Unpleasant Monetarist Arithmetic," Federal Reserve Bank of Minneapolis Quarterly Review, 5(Fall), 1-17.

Sims, C. A. (1988): "Identifying Policy Effects," in Empirical Macroeconomics for Interdependent Economics, ed. by e. a. Bryant, Ralph C., pp. 308-321. The Brookings Institution, Washington, DC.

Wallace, N. (1981): "A Modigliani-Miller Theorem for Open-Market Operations," American Economic Review, 71(3), 267-274.

Woodford, M. (1998): "Control of the Public Debt: A Requirement for Price Stability?," in The Debt Burden and Its Consequences for Monetary Policy, ed. by G. Calvo, and M. King, pp. 117-154. St. Martin's Press, New York.

(2003a): Interest and Prices: Foundations of a Theory of Monetary Policy. Princeton University Press, Princeton, N.J.

(2003b): Interest and Prices: Foundations of a Theory of Monetary Policy. Princeton University Press, Princeton, N.J. 


\begin{tabular}{ccccc}
\hline \multicolumn{3}{c}{ Active } & \multicolumn{2}{c}{ Passive } \\
\hline State & $S_{t}^{M}=1$ & $S_{t}^{M}=2$ & $S_{t}^{M}=3$ & $S_{t}^{M}=4$ \\
\hline \hline$\alpha_{0}$ & .0068 & .0068 & .0058 & .0058 \\
& $(.0005)$ & $(.0005)$ & $(.0002)$ & $(.0002)$ \\
& & & & .5305 \\
$\alpha_{\pi}$ & 1.2936 & 1.2936 & .5305 & $(.02)$ \\
& $(.062)$ & $(.062)$ & $(.02)$ & \\
& & & & .0485 \\
$\alpha_{y}$ & .0249 & .0249 & .0485 & $(.0046)$ \\
& $(.005)$ & $(.005)$ & $(.0046)$ & \\
& & & & \\
$\sigma_{r}^{2}$ & $1.61615 \mathrm{e}-005$ & $9.18552 \mathrm{e}-007$ & $2.07447 \mathrm{e}-005$ & $5.51202 \mathrm{e}-007$ \\
& $(9.67157 \mathrm{e}-006)$ & $(1.95885 \mathrm{e}-006)$ & $(3.4185 \mathrm{e}-006)$ & $(1.75348 \mathrm{e}-006)$ \\
\hline
\end{tabular}

TABLE 1. Monetary policy rule estimates. Log likelihood value $=-1079.52$.

\begin{tabular}{ccc}
\hline State & $S_{t}^{F}=1$ & $S_{t}^{F}=2$ \\
\hline \hline$\gamma_{0}$ & .029 & .004 \\
& $(.0025)$ & $(.0036)$ \\
$\gamma_{b}$ & .071 & -.025 \\
& $(.0044)$ & $(.0066)$ \\
$\gamma_{y}$ & .498 & .324 \\
& $(.025)$ & $(.035)$ \\
$\gamma_{g}$ & .409 & 1.022 \\
& $(.026)$ & $(.030)$ \\
$\sigma_{\tau}^{2}$ & $4.25 \mathrm{e}-5$ & $4.98 \mathrm{e}-005$ \\
& $(6.82 \mathrm{e}-6)$ & $(8.58 \mathrm{e}-6)$ \\
\hline
\end{tabular}

TABLE 2. Tax policy rule estimates. Log likelihood value $=-820.76$. 
EXPECTATIONS AND FISCAL STIMULUS

\begin{tabular}{lcccc}
\hline \multicolumn{5}{c}{$\frac{P V(\Delta Y)}{P V(\Delta G)}$ after } \\
Regime & 5 quarters & 10 quarters & 25 quarters & $\infty$ \\
\hline \hline & & .80 & .84 & .86 \\
$\mathrm{AM} / \mathrm{PF}$ & .79 & 1.51 & 1.39 & 1.37 \\
$\mathrm{PM} / \mathrm{PF}$ & 1.64 & 1.58 & 1.4 & 1.36 \\
$\mathrm{PM} / \mathrm{AF}$ & 1.72 & Note: $\frac{P V(\Delta C)}{P V(\Delta G)}=\frac{P V(\Delta Y)}{P V(\Delta G)}-1$.
\end{tabular}

TABlE 3. Present value multipliers from the regime-switching model.

\begin{tabular}{lccc}
\hline & \multicolumn{3}{c}{$\% \Delta P$ after } \\
Regime & 5 quarters & 10 quarters & 25 quarters \\
\hline \hline & & & \\
$\mathrm{AM} / \mathrm{PF}$ & .76 & 1.34 & 2.37 \\
$\mathrm{PM} / \mathrm{PF}$ & 2.19 & 3.18 & 3.98 \\
$\mathrm{PM} / \mathrm{AF}$ & 2.41 & 3.40 & 3.95 \\
\hline
\end{tabular}

TABLE 4. Impact of a $3 \%$ increase in government purchases on the price level in the regime-switching model.

\begin{tabular}{|c|c|c|c|c|}
\hline \multirow[b]{2}{*}{ Regime } & \multicolumn{4}{|c|}{$\frac{P V(\Delta Y)}{P V(\Delta G)}$ after } \\
\hline & 5 quarters & 10 quarters & 25 quarters & $\infty$ \\
\hline
\end{tabular}

No Foresight-AR $(1)$

$\begin{array}{lcccc}\mathrm{AM} / \mathrm{PF} & .68 & .68 & .68 & .68 \\ \mathrm{PM} / \mathrm{AF} & 3.29 & 2.88 & 2.41 & 2.3\end{array}$

Foresight-ARMA $(1,5)$

$\begin{array}{lcccc}/ \mathrm{PF} & .52 & .61 & .63 & .63 \\ \mathrm{PM} / \mathrm{AF} & 4.83 & 3.10 & 2.31 & 2.17\end{array}$

TABLE 5. Present value multipliers from the fixed-regime model; with and without foresight. 
Active Monetary Policy, High $\sigma$
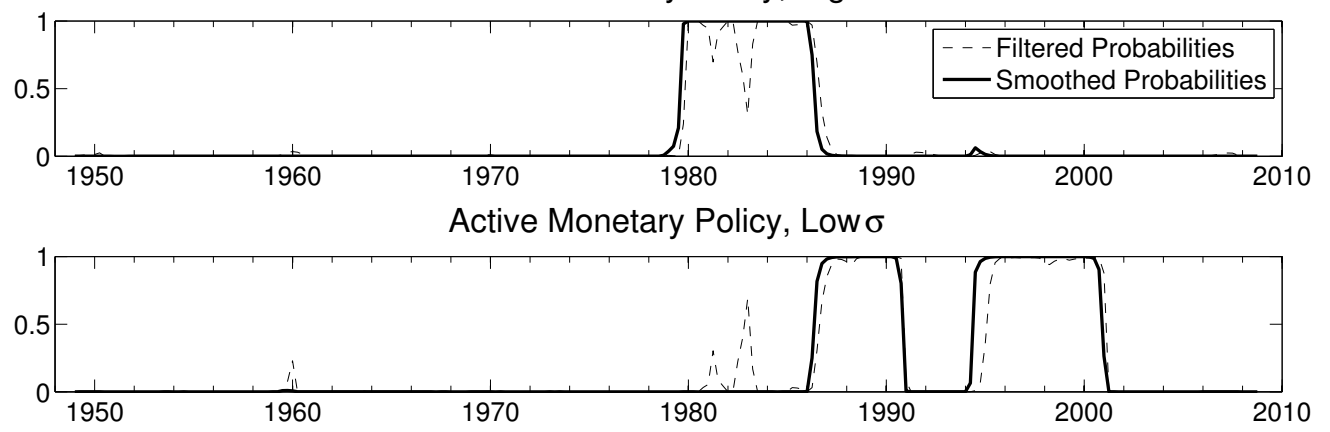

Passive Monetary Policy, Higho

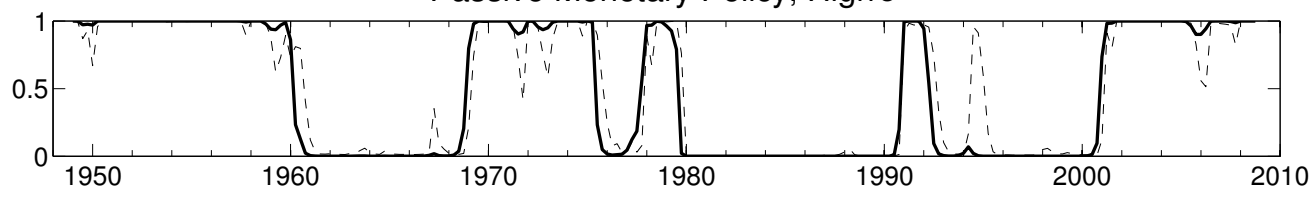

Passive Monetary Policy, Low $\sigma$

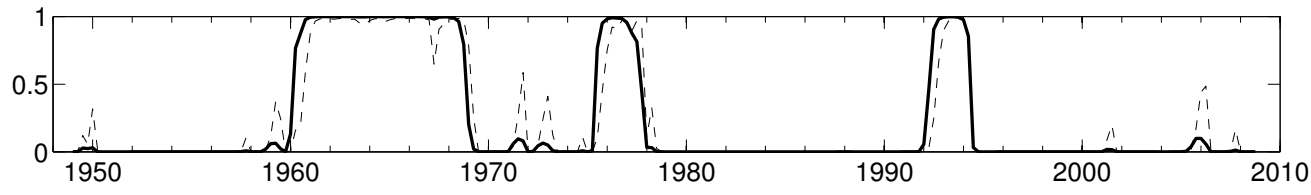

FiguRe 1. Monetary Regime Probabilities 


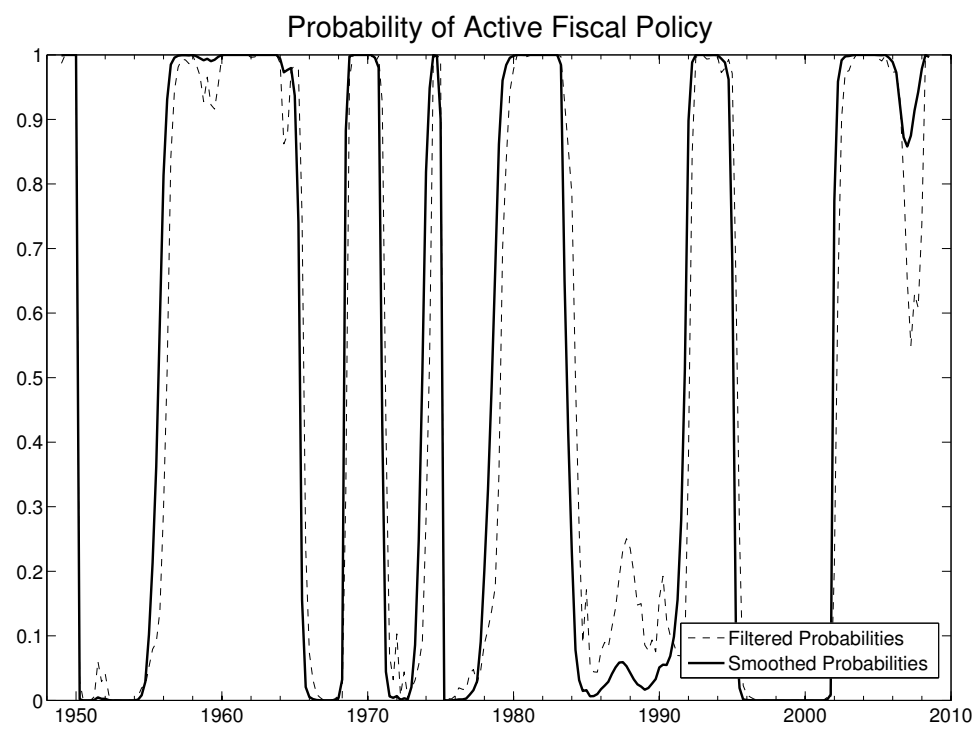

Figure 2. U.S. Fiscal Regime Probabilities

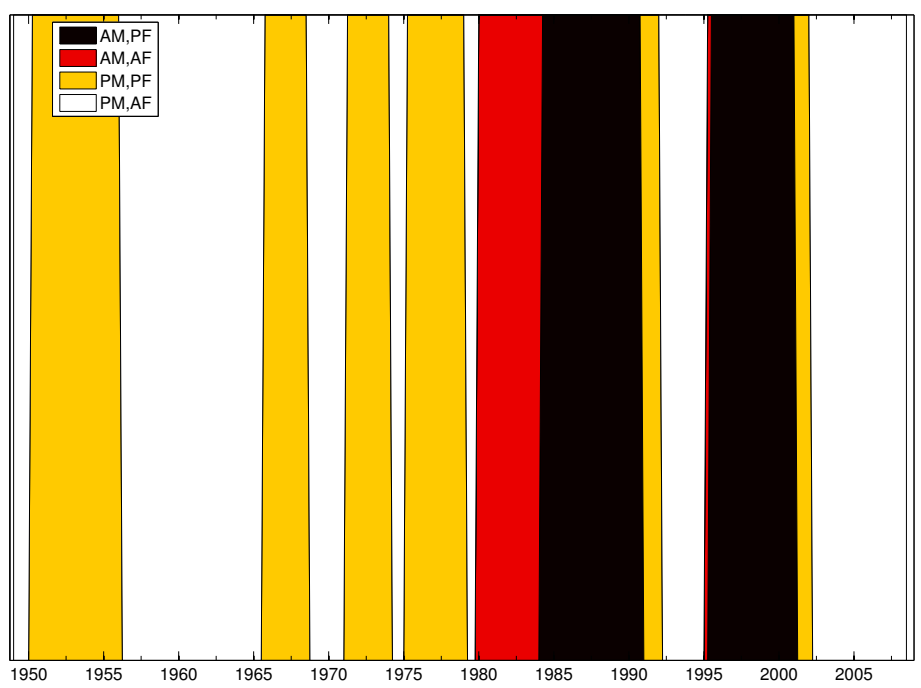

Figure 3. U.S. Monetary and Fiscal Regimes 

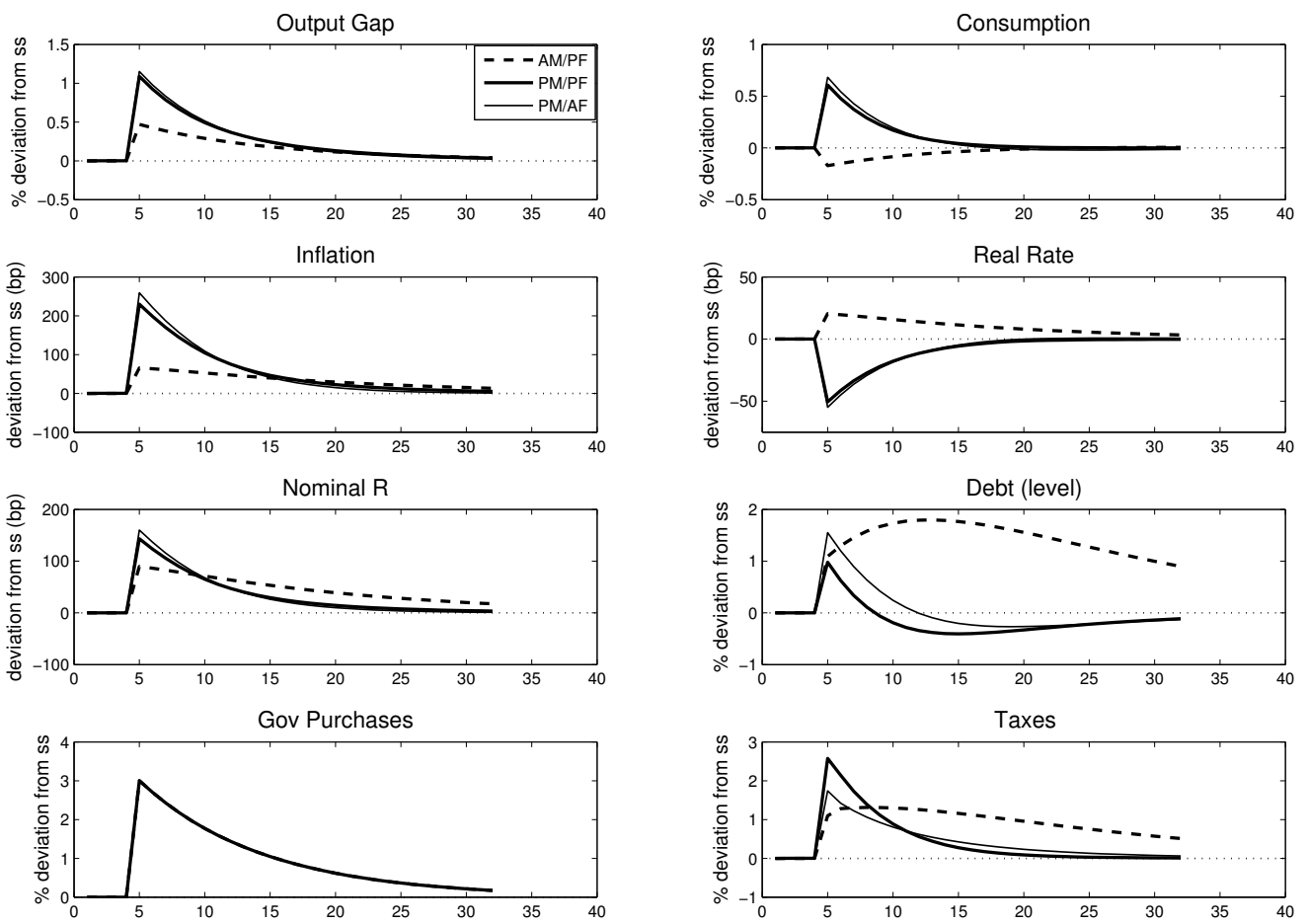

FIGURE 4. Shock to government purchases conditioning on regime 

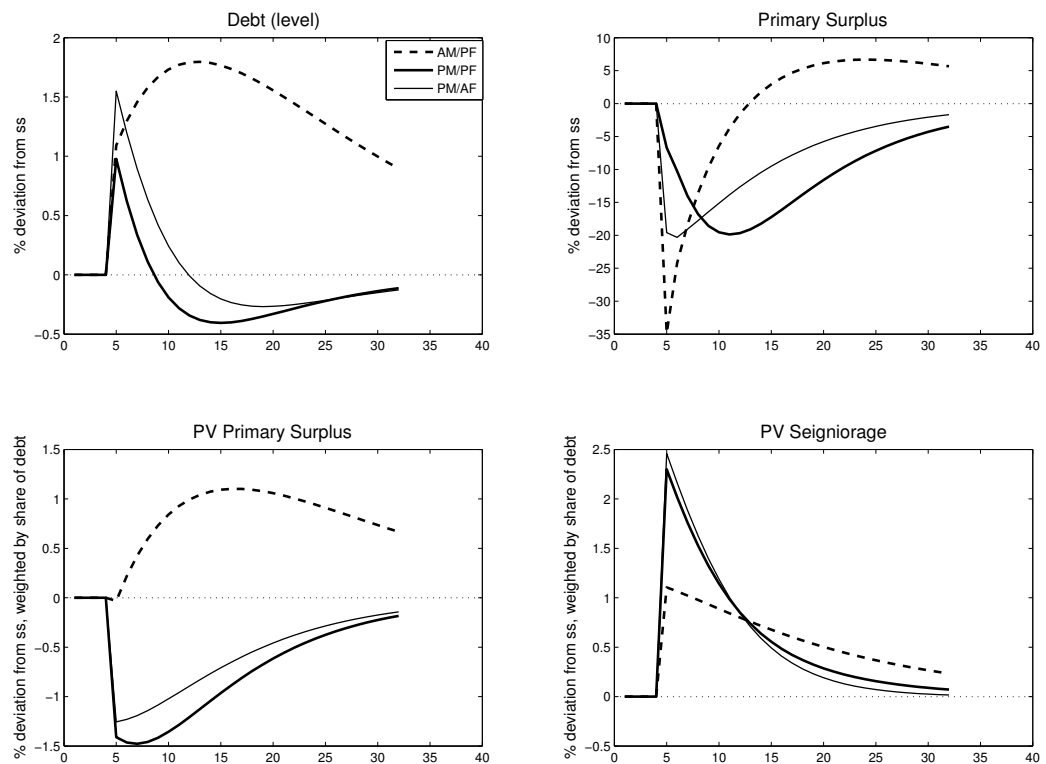

FiguRE 5. Fiscal variables response to shock to government purchases conditioning on regime
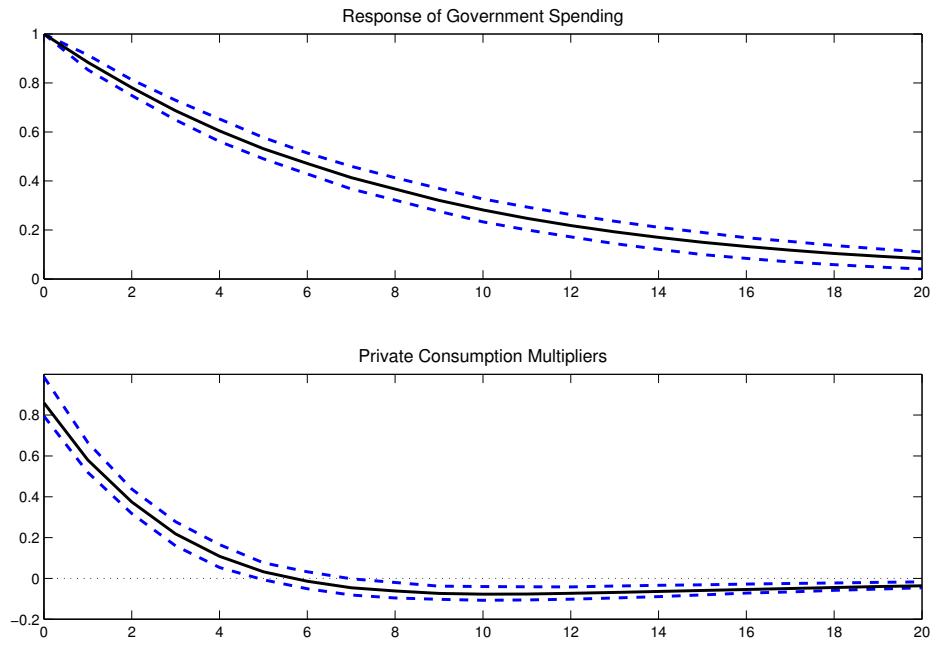

Figure 6 . Consumption multipliers from VAR fit to simulated data from the regime-switching model 

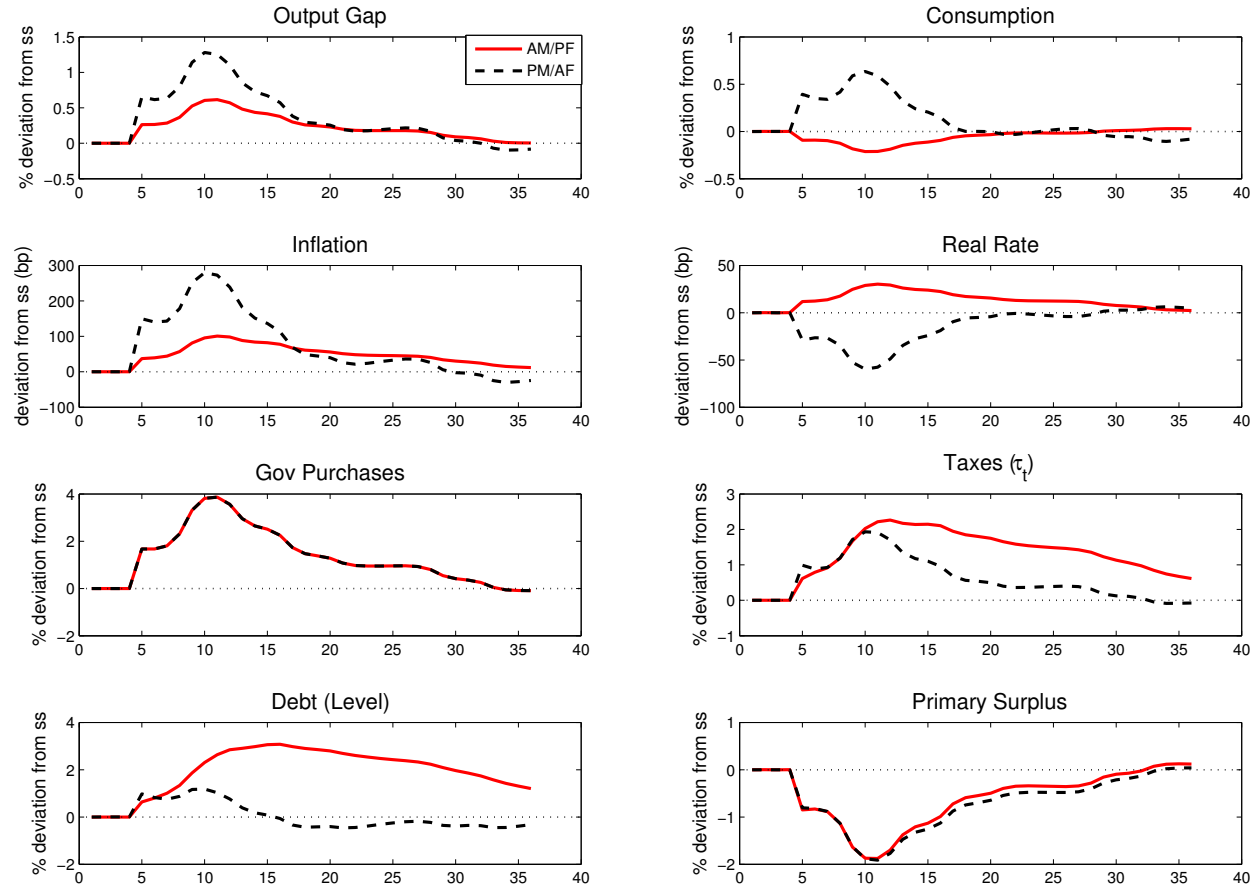

FiguRE 7. Simulating the 2009 ARRA under different monetary-fiscal regimes 

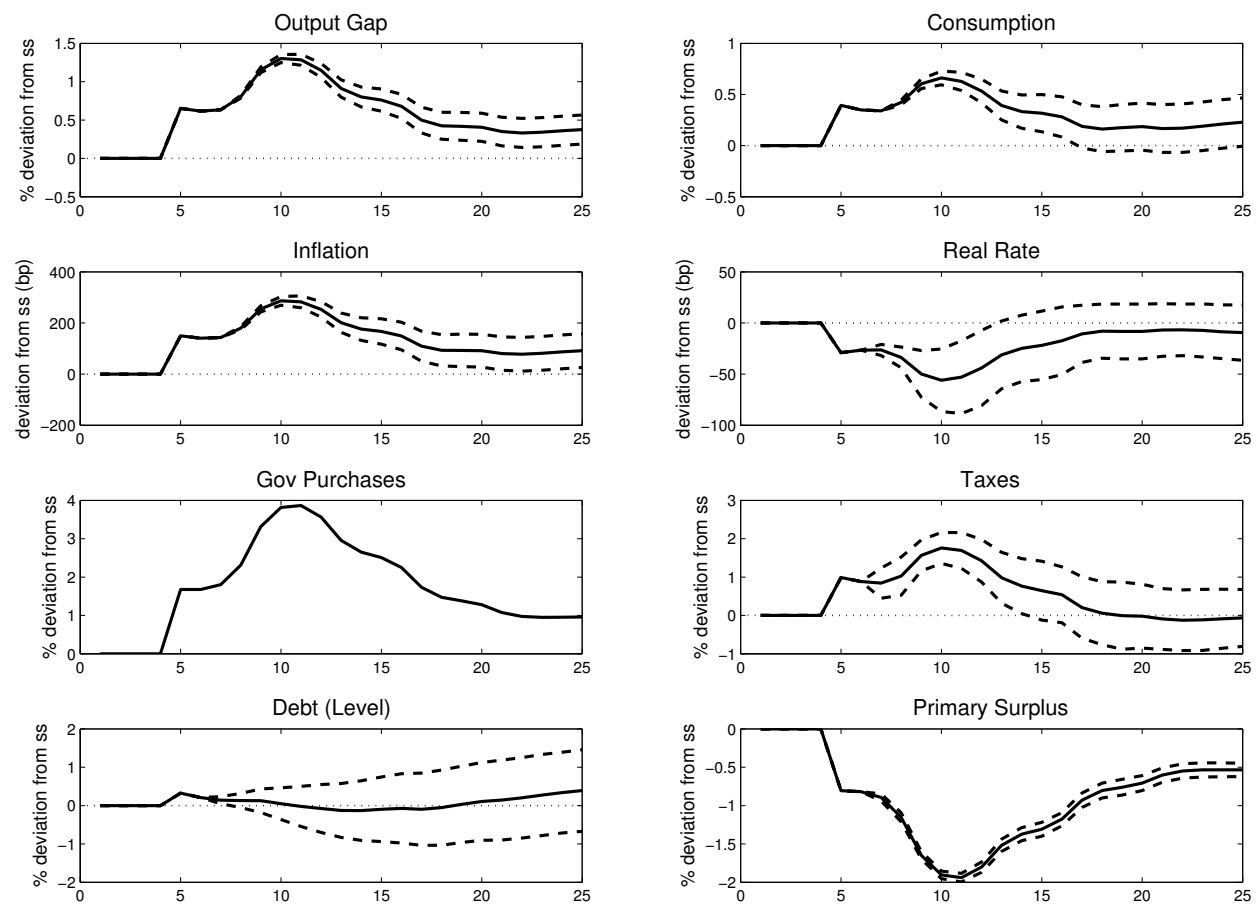

FIGURE 8. Simulating the 2009 ARRA randomly drawing over future monetary and fiscal regimes 